Article

\title{
Our Social Discontents: Revisiting Fromm's Redemptive Psychoanalytic Critique
}

\section{lan Raymond B. Pacquing}

\begin{abstract}
Modern society is marked with utmost ambivalence. There is the utmost desire to be free, creative, and productive. Yet, our creative and productive desires trap us and now control our own freedom to become. Couple this inconsistency with the rapid sociostructural changes, fragmentation of traditions, and dissolution of communal well-being, what we have is a life of uncertainty. It is a life debased from its very ontological foundation with the transmission of technorationalities of the capitalist industry. In modernity, we could no longer speak of individuality and subjectivity since the very historical thread that serve as its foundation is now wavered towards accumulation and possession of the capital. Moreover, this overleaning towards the capital deadens us unconsciously that we mistake this for reality. The market ideology with all its rationalizations reifies human consciousness to the extent that we consider the technorationalities as the ontological normative structure. As a result, there is a growing dislocation of subjectivity which leads to neurotic social behaviors and inner social contradictions. As a result, we have our own social discontents. It is then the aim of this paper to ponder on the psychosocial effects of the market economy. I argue that there is a need to look at the effects of this economic system that perpetually delineate subjective experiences and plunge humanity into incontrovertible pseudo images. It is at this point that Fromm's radical psychosocial interpretation of society becomes binding. I argue with Fromm that our social libidinal drives or what he termed as social characterology, which we are all unconscious of, must be thoroughly brought to fore. I claim that this particular characterology result to the obstructions of a normal and healthy society.
\end{abstract}

Keywords: psychoanalysis, subjectivity, individuality, social characterology

(c) 2018 lan Raymond B. Pacquing

https://www.kritike.org/journal/issue 22/pacquing_june2018.pdf

ISSN 1908-7330 


\section{FROMM'S REDEMPTIVE PSYCHOANALYTIC CRITIQUE}

W

hy does a radical psychology matter in our postmodern times? ${ }^{1}$

Freud's contribution to modernism highlights a revolution inasmuch as our era is characterized by tremendous restlessness, shattering of cultures and beliefs, and the disillusionment of the self. ${ }^{2} \mathrm{His}$ psychoanalytic method has laid bare a methodology and epistemology which pronounces a metanarrative that has been authoritarian and oppressive. ${ }^{3}$ Freud's philosophy challenges our sociostructural conditions which replicate the metanarrative of modernity. ${ }^{4}$ In this sense, Freud's metapsychology transforms the way we think about ourselves, i.e., he has shown "how little we are in control of our own fcthought processes." 5 However, although Freudian psychoanalysis has provided us with so many reprieves from our miseries, it must also be noted that his intellectual genius is only focused on the physiological and biological influence of our instincts. He has thought that every group or class is just composed of individuals who are the only subject of psychic properties. ${ }^{6}$ Freud just limits himself with psychic traits which are common to all people regardless of their historical origins. ${ }^{7} \mathrm{He}$ has engrossed himself with the instinctual drives which he takes as the causes of our miseries. ${ }^{8}$ Freud has focused so much on the phylogenetic and

1 Pekkola describes modernity as ambivalent: it promises progress for humanity through the creation of a new man and a new society, yet it destroys the traditional forms of life and authority. He further says, "The sensations of loss, of the disappearance of foundations and of the dissolution of meanings and points of reference were pivotal for almost all critical analyses of modernity and its crisis." See Mikka Pekkola, "Prophet of Radicalism: Erich Fromm and the Figurative Constitution of the Crisis of Modernity" (Ph.D. Dissertation, University of Jyvaskyla, 2010), 10. In this sense, the propagation of ideologies construed from modernity's ambivalent nature resulted in the experimentation of modern psychology of multiple ways of knowing and understanding human behavior. However, we seldom realize that psychology is incorporated as a medium towards domination and exploitation. Parker explains that psychology becomes a powerful component for the ruling ideology in order to maintain its power and domination. See Ian Parker, Revolution in Psychology: Alienation to Emancipation (London: Pluto Press, 2007), 2. Even Chomsky admits that psychological mechanisms, in controlling those who are in the middle class through investments and benefits, retain the power of capitalist hegemony. See Noam Chomsky, Profit Over the People: Neoliberalism and the Global Order (New York: Seven Stories Press, 1999), 53.

${ }^{2}$ See Roger Horrocks, Freud Revisited: Psychoanalytic Themes in the Postmodern Age (New York: Palgrave Macmillan, 2001), 9-10.

${ }^{3}$ See ibid.

${ }^{4}$ See Amy Buzby, Subterranean Politics and Freud's Legacy: Critical Theory and Society (New York: Palgrave Macmillan, 2013), 12.

${ }^{5}$ Nick Rennison, Freud and Psychoanalysis (London: Pocket Essentials, 2001), 82-85.

${ }^{6}$ See Erich Fromm, The Crisis of Psychoanalysis: Essays on Freud, Marx, and Social Psychology (New York: Henry Holt and Company, 1970), 142-144.

7 See Erich Fromm, "Man's Impulse Structure and Its Relation to Culture," in Beyond Freud: From Individual to Social Psychology, ed. by Rainer Funk (New York: American Mental Health Foundation, 2010), 17-74.

8 Douglas Kellner, "Erich Fromm, Feminism, and the Frankfurt School" (paper presented at the International Interdisciplinary Symposium on Erich Fromm and the Frankfurt

(C) 2018 lan Raymond B. Pacquing

https://www.kritike.org/journal/issue 22/pacquing june2018.pdf

ISSN 1908-7330

(cc) BY-NC-ND 
ontogenetic causal roles to sexuality, ${ }^{9}$ thereby lessening the effect of the unconscious forces of history to the individual. ${ }^{10}$ Freudian psychoanalysis, then, considers man to be a "physiologically driven and motivated homme machine." 11

However, I would like to argue that in the process of our assimilation and socialization with our immediate environment, our instinctual drives are as much a product of our social milieu. Fromm argues that Freud did not consider the individual as an isolated man devoid of any social ties. He quotes Freud:

In the individual's psychic life, other people ordinarily must be considered as models, objects, helpers, or opponents. Thus, from the beginning, individual psychology is simultaneously social psychology - in this extended but legitimate sense. ${ }^{12}$

Moreover, Freud has also insisted in his book, Civilization and Its Discontents, that our repressed instinctual drives are caused by the powerful social forces inflicted upon us to the extent that we need to suspend them in order for society to flourish. ${ }^{13}$ The preservation of life interacts with the gratification of the sexual instincts. The reverse is also true. The satisfaction of the sexual instincts must follow the lead of the instinct on self-preservation. Both of them must interact with the dynamics of the social sphere. ${ }^{14}$ In other words, there is a fundamental link between what is in our individual psychic drives and the forces emanating from our immediate environment. This is what makes the radical position of Fromm relevant. He asks "what role the instinctual and the unconscious play in the organization and development of society and in individual social facts, and to what extent they change

School, Stuttgart-Hohenheim, 31 May to 2 June 1991), <https://pages.gseis.ucla.edu/faculty/ kellner/Illumina\%20Folder/kell8.htm>.

9 See Kieran Durkin, The Radical Humanism of Erich Fromm (New York: Palgrave Macmillan, 2014), 70.

${ }^{10}$ See Frank Sulloway, "Reassessing Freud's Case Histories: The Social Constructions of Psychoanalysis," in Isis, 82:2 (June 1991), 246.

${ }^{11}$ Durkin, The Radical Humanism, 72.

12 Sigmund Freud, Group Psychology and the Analysis of the Ego, as cited from Fromm, The Crisis of Psychoanalysis, 143. Cf. Sigmund Freud, Group Psychology and the Analysis of the Ego, in The Standard Edition of the Complete Psychological Works of Sigmund Freud, vol. 18, ed. and trans. by James Strachey (London: Hogarth Press), 71.

${ }^{13}$ See Sigmund Freud, Civilization and Its Discontents, trans. by James Strachey (New York: W.W. Norton \& Company, 1961), 49.

${ }^{14}$ See ibid., 42.

(c) 2018 Ian Raymond B. Pacquing

https://www.kritike.org/journal/issue 22/pacquing_june2018.pdf

ISSN 1908-7330 


\section{FROMM'S REDEMPTIVE PSYCHOANALYTIC CRITIQUE}

mankind's psychological structure ... is a sociologically relevant factor." ${ }^{15} \mathrm{He}$ continues, "Just as, for Freud, it is always socialized man who is the object of psychology, so he sees man's environment and living conditions playing a decisive role in his psychic development and in our theoretical understanding of it." 16

After Freud, psychoanalysis became a very influential tool to expose social contradictions brought about by our interaction with our immediate environment. The interplay between the satisfactions of our instincts within the social structures led Fromm to assert that there is a connection between the material forces of society and the psychic apparatus of men. He asserts, "The active and passive adaptation of the biological apparatus, the instincts, to social reality is the key conception of psychoanalysis." 17 How man finds his own satisfaction within the ambit of the social structures and to what extent is his satisfaction become, then, the question of analytic social psychology. He further adds:

The thesis that psychology only deals with the individual while sociology only deals with "society" is false. For just as psychology always deals with the socialized individual, so sociology always deals with a group of individuals whose psychic structure and mechanisms must take into account. ${ }^{18}$

Nonetheless, we have to take into account that the effects of our social environment set our thoughts into a reeled construction of "clichés, ideas, rationalizations, and ideologies which fill people's minds and which form the basis of what they mistake for reality." 19 Fromm, then, asserts that what we consciously think is "false," and that it is a product of wrong ideology and rationalization. Elaborating Freudo-Marxist thinking, he says:

${ }^{15}$ See Erich Fromm, "Psychoanalysis and Sociology," in Critical Theory and Society: A Reader, trans. by Mark Ritter, ed. by Stephen Bronner and Douglas Kellner (New York: Routledge, 1989), 38. See also Fromm, "Man's Impulse Structure and Its Relation to Culture."

${ }^{16}$ Fromm, The Crisis of Psychoanalysis, 144.

17 See ibid., 141.

${ }^{18}$ See ibid., 142

${ }^{19}$ Erich Fromm, Beyond the Chain of Illusion (London: Simon and Schuster, 1962), 10. Karl Korsch argued that the lack of the sociopsychological dimension of Marxism led to its collapse after the war in 1918. That is why the Freudian-Marxist theories as imbibed by the members of the Frankfurt School were used to base their own findings on the psychosociological aspects of society. See John Rickert, "The Fromm-Marcuse Debate: Revisited," in Theory and Society, 15:3 (May 1986), 352.

(C) 2018 lan Raymond B. Pacquing

https://www.kritike.org/journal/issue 22/pacquing june2018.pdf

ISSN 1908-7330

(c) $\mathrm{BY}-\mathrm{NC}-\mathrm{ND}$ 
It should be noted that Marx, like Spinoza and later Freud, believed that most of what men consciously think is "false" consciousness, is ideology and rationalization; that the true mainsprings of man's actions are unconscious to him. According to Freud, they are rooted in man's libidinal strivings; according to Marx, they are rooted in the whole organization of man which directs his consciousness in certain directions and blocks him from being aware of certain facts and experiences. ${ }^{20}$

Fromm, thus, wanted to understand social contradictions by examining the psychological processes operating within the individual. ${ }^{21} \mathrm{His}$ approach is of psychosocial interest, i.e., he wanted to find out why many people behave irrationally in similar ways. ${ }^{22}$ He now argues,

I tried to show that we cannot understand people by their ideas and ideologies; that we can understand ideas and ideologies only by understanding the people who created them and believed in them. In doing this we have to transcend individual psychology and enter the field of psychoanalyticsocial psychology. ${ }^{23}$

To make this happen, he needs to situate the individual into larger social contexts, i.e., economic, political, social, and cultural aspects. ${ }^{24}$ Hence, "analytical social psychology seeks to understand the instinctual apparatus of a group, its libidinous and largely unconscious behavior, in terms of its socioeconomic structure." 25 Social Psychoanalysis, then, is entitled and competent to say something about the motives underlying social behavior. ${ }^{26}$

\footnotetext{
${ }^{20}$ Erich Fromm, Marx's Concept of Man (London: Continuum, 1961), 19.

${ }^{21}$ See Erich Fromm, Foreword to Fear of Freedom (New York: Farrar \& Rinehart, 1942), ix.

22 See Rainer Funk, Foreword to Reclaiming the Sane Society: Essays on Erich Fromm's Thought, ed. by Seyed Javad Miri, Robert Lake, and Tricia M. Kress (Rotterdam: Sense Publisher, 2014), 2.

${ }^{23}$ Erich Fromm, Foreword to The Dogma of Christ and Other Essays on Religion, Psychology, and Culture (New York: Rinehart and Co., 1955), viii-ix. Emphasis mine.

${ }^{24}$ See Irene Rosenberg Javors, "Revisiting Beyond the Chains of Illusion: My Encounter with Marx and Freud: Reflections on Fromm's Theory and Practice within the Psychotherapeutic Encounter," in Reclaiming the Sane Society, 215.

${ }^{25}$ Fromm, Crisis of Psychoanalysis, 144.

${ }^{26}$ See Erich Fromm, "The Method and Function of an Analytic Social Psychology," in The Essential Frankfurt School Reader, ed. by Andrew Arato and Eike Gebhardt (New York: Continuum, 2002), 481.
} 


\section{FROMM'S REDEMPTIVE PSYCHOANALYTIC CRITIQUE}

It is here that we come to understand how our conscious life is modified by the prevailing material social forces. ${ }^{27}$ In the words of Golding,

... what psychoanalysis reveals about the workings of the unconscious not only helps to clarify the mechanisms by which society enters into the individual but also challenges our most basic assumptions about what it means to be conscious. The relationship between individual and society is complex, tense, and contradictory and psychoanalysis can show us why. ${ }^{28}$

Central to Fromm's psychosocial theory is the effect of the socioeconomic base of a particular society. ${ }^{29}$ Taking the lead from Marx's famous maxim that our world determines how we think, ${ }^{30}$ Fromm develops his concept of the social character. ${ }^{31} \mathrm{He}$ argues that in the process of acquisition and assimilation with the social sphere, there is a necessity to adapt ourselves for the satisfaction of our instinctual drives. The means of productions, the social stratifications, and social communications are all arranged and activated through those social libidinal impulses so that social energies are swayed towards the survival of society and particularly for our

27 See Christopher Lasch, The Culture of Narcissism (New York: W.W. Norton and Company, 1979), 34.

${ }^{28}$ Robert Golding, "Freud, Psychoanalysis, and Sociology: Some Observations on the Sociological Analysis of the Individual," in The British Journal of Sociology, 33:4 (December 1982), 547.

${ }^{29}$ See Fromm, "Psychoanalysis and Sociology," 38. See also Fromm, "Man's Impulse Structure and Its Relation to Culture," 37.

${ }^{30}$ See Karl Marx, A Contribution to the Critique of Political Economy, trans. by N.I Stone (Chicago: Charles H. Kerr and Company, 1904), 11-12.

${ }^{31}$ See Erich Fromm, The Sane Society (Canada: Holt, Rinehart, and Winston, 1955), 78. See also Fromm, Fear of Freedom, 238. Marcuse and the rest of the Frankfurt School have accused Fromm of revisionism. Marcuse contends that Fromm's interpretation of Freudian psychoanalysis is naïve and does not advance a critique of industrial capitalism. For Marcuse, faithfulness to the original intent of Freud's instinct and libido theories is a necessity for a critique of modern capitalism. According to Buzby, Marcuse contends that Fromm's revision of Freudian libido theories, lacks the "explosive, countercultural vision necessary to transform thought and practice." Further, Fromm's reinterpretation of Freud looks for the utopian vision which rests on the promises of Enlightenment Humanism. See Buzby, Subterranean Politics and Freud's Legacy, 106-109. However, Fromm responded on this criticism arguing, among others, that in the interaction between the individual and society, the social libidinal drive is activated and formed into what he has termed as social character. Thus, Freud, says Fromm, has wrongly based the instinctual theory on natural factors alone. The social characterology are the traits that are common to the members of a group or class so that the social characterology explains the social behavior or traits inherent in that group or class. See Rickert, "The Fromm-Marcuse Debate Revisited," 354.

(C) 2018 lan Raymond B. Pacquing

https://www.kritike.org/journal/issue 22/pacquing_june2018.pdf

ISSN 1908-7330

(c) BY-NC-ND 
own survival. ${ }^{32}$ Unconsciously, we have to act and find gratification in our action in accordance to the required demands for the smooth functioning of society. ${ }^{33}$ Social character, then, is a psychic dynamism where the ruling economic and political ideologies are unconsciously disseminated. ${ }^{34}$ Our libidinal impulses, for Fromm, express and maintain the socially mandated patterns through which the individual relates to the world around him. ${ }^{35}$ As we unconsciously imbibe a particular social characterology, we either regress or progress in our evolution as human beings. ${ }^{36}$ Ideologies, rationalization, and clichés form a particular social characterology that either enhances or impedes our growth and productivity. Since our engagements with the social sphere undertake a radical position where the political, economic, and sociocultural dimensions are imperatives, I argue that there is a need to look at the psychosocial dynamics of our society, i.e., our social characterology as a powerful instrument for the maintenance of the socioeconomic mainstream. ${ }^{37} \mathrm{I}$ contend, therefore, that there is a need to look at how our society, particularly its socioeconomic structures, shakes the social libidinal impulses and thus affects our lives. I think this is where the psychosocial philosophy of Fromm becomes relevant to our contemporary times. ${ }^{38}$

Nevertheless, our contemporary society with a technocapitalist characterology has brought us towards spilling and thrilling. Its rapidity and fast-paced influence has led human consciousness towards a revolutionary change with regard to our epistemic paradigm, i.e., our way of looking at the world as now dependent upon market-based rationality. ${ }^{39}$ Human reason

32 See Rainer Funk, "Erich Pinchas Fromm and the Social Character," in The Edinburgh International Encyclopedia of Psychoanalysis, ed. by Ross M. Skelton (Edinburgh: Edinburgh University Press, 2006), 3-4.

${ }^{33}$ See Fromm, The Sane Society, 77-78.

${ }^{34}$ See Parker, Revolution in Psychology, 2.

35 See Stephen A. Mitchell, Influence and Autonomy in Psychoanalysis (London: Routledge, 2013), 66.

${ }^{36}$ See Ferenc Erös, "Wilhelm Reich, Erich Fromm and the Analytical Social Psychology of the Frankfurt School," in the Erich Fromm Document Center (1992), < $\underline{\text { https://opus4.kobv.de/ }}$ opus4-Fromm/files/8829/Eroes F 1992.pdf >. First published in Michael Kessler and Rainer Funk, eds., Erich Fromm und die Frankfurter Schule (Tübingen: Francke Verlag, 1992), 69-72.

${ }^{37}$ See Parker, Revolution in Psychology: Alienation to Emancipation, 7.

38 Funk describes it further. He says, "Fromm proposes to follow Karl Marx in examining social structure as determined by economic factors. If such a determination of social structure is discoverable, it must be asked whether psychic structure is not also shaped by socioeconomic conditions through the family as the psychological agency of society. If so, socioeconomic conditions rather than libidinous energy have the primary shaping influence. In that case, it would not be the structure of drives that determines man's nature and behavior; instead in the interplay of interacting psychic drives and economic conditions, the latter have primacy." Rainer Funk, Erich Fromm: The Courage to Be Human (New York: Continuum, 1982), 17. 2005), 39-40.

${ }^{39}$ See David Harvey, Brief History of Neoliberalism (New York: Oxford University Press,

(c) 2018 Ian Raymond B. Pacquing

https://www.kritike.org/journal/issue 22/pacquing june2018.pdf

ISSN 1908-7330

(cc) BY-NC-ND 


\section{FROMM'S REDEMPTIVE PSYCHOANALYTIC CRITIQUE}

and affections become apparatuses for the propagation of an irrational ideology which we all mistake for reality. The conscious elements of human adaptation and assimilation have yielded to the instrumentalization of life. Even moral and ethical lives are objectified as a result of human commodification. Honneth remarks that it is the "commercialization" of everyday life where human and individual relationships "interact with a lifeless object without a trace of inner sentiment or any attempt at understanding the other's point of view." 40 This is the irrationality of our rationality as human beings. ${ }^{41}$ As a result, we dwell on our ego-oriented machinery where we reconstruct our world without any limitation, without any boundaries, as long as the parameters of life suit our innermost narcissistic desires. ${ }^{42}$ Life experiences are already determined from this "Iam-me orientation." Life is no longer bounded by the external moral necessities but rather, an innermost desire to pump up those instinctual libidinal strivings. ${ }^{43}$ Everything is measured by the way the individual maps his very own world. There is no relation, no sense of commitment. Everything is centered on the self. The arbiter of our sociopolitical life is the "me" grounded on its very capacity to see itself and the world. Normative discourses make sense if it satiates this "me mentality" that inflates the ego ideal. ${ }^{44}$ In other words, as the culture of individualism is greatly emphasized and continuously evolved, the more he is decentered from the community. Safran articulates this when he says "On the one hand, the more individuated person of contemporary culture is freer of the potentially suffocating influence of the community. On the other, he or she is cut off from the sense of meaning and well-being that potentially flows from being integrated with the wider community." 45 Contemporary man, says Fromm, does not experience himself as the active bearer of his own power and richness. ${ }^{46} \mathrm{With}$

${ }^{40}$ Axel Honneth, Reification: A New Look at an Old Idea, ed. by Martin Jay (New York: Oxford University Press, 2008), 18.

${ }^{41}$ See George Ritzer, McDonaldization: The Reader (London: Fine Forge Press, 2002), 20-

25.

${ }^{42}$ See Rainer Funk, "The Striving for Unboundedness and Its Impact on Psychoanalytic Treatment," in Fromm Forum: Annual Publication of the International Erich Fromm Society, English ed., 17 (2013), 22-28.

${ }^{43}$ See Rainer Funk, "Living by the manual: Ego-oriented social character-pathogenic effects of globalization," in International Forum of Psychoanalysis 19:2 (2010), 84-91.

${ }^{44}$ Fromm eloquently discusses the narcissistic tendency of one whose ego is inflated due to the accumulation and consummation of goods and services. See Erich Fromm, Heart of Man: Its Genius for Good and Evil (New York: Harper and Row, 1964), 39. See also Erich Fromm, "Selfishness and Self-Love," in Yearbook of the International Erich Fromm Society, 5 (1994), 173-197.

45 Jeremy D. Safran, "Introduction: Psychoanalysis and Buddhism as Cultural Institutions," in Psychoanalysis and Buddhism: An Unfolding Dialogue, ed. by Jeremy D. Safran (Boston: Wisdom Publications, 2003), 6.

${ }^{46}$ See Fromm, The Sane Society, 121.

(C) 2018 lan Raymond B. Pacquing

https://www.kritike.org/journal/issue 22/pacquing june2018.pdf

ISSN 1908-7330

(cc) BY-NC-ND 
the fragmentation of our culture, traditions and beliefs, we are left nowhere but to anchor ourselves unto this kind of rationality "I-am-me" orientation where everything is now culturally permitted. ${ }^{47}$ Lasch believes that, with no solid foundation to hold on to, our lives lead increasingly to narcissistic mentality. ${ }^{48}$ Hence, we are just tossed to and fro in multiplicity, fluidity, and contradictions, resulting to spilling and thrilling in the world of the capital. ${ }^{49}$ As Zima says, the "market value as exchange value deprives the individual subject of his singularity by making him comparable to all others." 50 In other words, the web of traditions and beliefs that we share as a common community have all faded away and what is left is the primacy of the market economy which leads to the emptying of the integral self. Thus, our society experiences a "chronic and undifferentiated emotional hunger." 51 Take for example the policies of deregulation and competition of neoliberal economy. Since its inception in the 70 s, we have been forced to negate intersubjective alliances and to focus our energies towards antagonistic individualism where social connectivity is cancelled. ${ }^{52}$ Ours is a disintegration of the subjective self where creative, productive, and effective communication of ideational content of the environment is lost. ${ }^{53}$ In this sense, people could no longer manage their collective and individual affairs. ${ }^{54}$ What we have instead is an alienated existence that does not sense any joy, love, or longing-no continuity of time and life. In other words, there is no self. ${ }^{55}$ We plunged into a "state of schizoid inability to experience affect, hence he [man] is anxious, depressed, and desperate." 56

${ }^{47}$ See Funk, “Living by the Manual," 84-91.

${ }^{48}$ See Lasch, The Culture of Narcissism, 11-12.

49 See Ian Raymond B. Pacquing, "Neoliberalism and the Paralysis of Human Rationality," in Kritike: An Online Journal of Philosophy, 10:1 (June 2016), 136. See also my other article entitled "Neoliberalism and our Precarious Culture," in Kritike: An Online Journal of Philosophy, 11:1 (2017), 129-148.

${ }^{50}$ Peter V. Zima, Subjectivity and Identity: Between Modernity and Postmodernity (London: Bloomsbury, 2015), 4.

${ }^{51}$ Safran, "Introduction: Psychoanalysis and Buddhism as Cultural Institutions," 7.

${ }^{52}$ See Mel Gray, "Perspectives on Neoliberalism for Human Service Professionals" in Social Service Review, 89:2 (June 2015), 2-7.

53 See Jeff Noonan, Critical Humanism and the Politics of Difference (London: McGill Queen's University Press, 2013), 43-46.

${ }^{54}$ See Noam Chomsky, "Market Democracy in a Neoliberal Order: Doctrines and Reality," in Z Magazine (1 November 1997), <https://zcomm.org/zmagazine/market-democracyin-a-neoliberal-order-doctrines-and-reality-by-noam-chomsky-1/>.

55 See Frederic A. Weiss, "Self-Alienation, Psychoanalysis and the Wholeness of Man," in Fortschritte der Psychoanalyse. Internationales Jahrbuch zur Weiterentwicklung der Psychoanalyse, vol. 1, ed by A. Heigl-Evers (Göttingen: Verlag für Psychologie - Dr. C. J. Hofgrefe, 1964), 3.

${ }^{56}$ Erich Fromm, Psychoanalysis and Zen Buddhism (New York: Open Road Media, 2013),

6.

(C) 2018 Ian Raymond B. Pacquing

https://www.kritike.org/journal/issue 22/pacquing june2018.pdf

ISSN 1908-7330

(cc) BY-NC-ND 


\section{FROMM'S REDEMPTIVE PSYCHOANALYTIC CRITIQUE}

Through a market driven characterology, our passionate strivings are primarily reflections of this particular characterology. It has institutionalized us as socialized a priori. ${ }^{57}$ Thus, our "thinking is not an exclusively intellectual process, and that it is bound up with the entire character structure. Doctrines, ideals, or even individual concepts have an 'emotional matrix' rooted in the character structure of the individual ..." 58 We now unconsciously satisfy our libidinal desires and rooting our life more on a paradigm based on "technorationalities of the culture industry." 59 Our lives are now truncated into instrumentalities, i.e., how we do things and no longer why we do these things. ${ }^{60}$ This pushes us further into a retrograde effect to be economic atoms who dance into the tune of economic management. ${ }^{61}$ However, the more we succumb into this lair, the more we fortify the socioeconomic system and thereby shuttering all the more our traditionally stable forms of identity, such as family, community, class, religion, and nationality. ${ }^{62}$ Hence, this characterology negates life's pulsations, tremors, and unpredictable movements which make it alive and meaningful, thereby transforming life

57 See Rainer Funk, "Fromm's Approach to Psychoanalytic Theory and Its Relevance for Therapeutic Work" (lecture given at the Instituto Mexicano de Psicoanálisis, A.C., 15 October 1992), <https://opus4.kobv.de/opus4-Fromm/files/9951/Funk R 1993h.pdf >.

${ }^{58} \mathrm{In}$ fact, Wilde captures what Fromm wants to convey as the essential nature of social characterology. The social character results upon the dialectic between the socioeconomic base and the ideological narrative of society. He says "The social character develops as an adaptation to changes in socioeconomic structure, and in turn, it influences the formation of ideas, doctrines, and even individual concepts. Reciprocally, the ideological superstructure then reinforces particular social characters that are functional for the further development of the socioeconomic structure. The social character operates as an internalization of external necessities and Fromm sees it as the harnessing of human energy for the tasks of a given economic and social system." Lawrence Wilde, Erich Fromm and the Quest for Solidarity (New York: Palgrave McMillan, 2005), 20.

${ }^{59}$ For a thorough discussion of the culture industry, see Max Horkheimer and Theodor Adorno, "The Culture Industry: Enlightenment as Mass Deception," in The Dialectic of Enlightenment, ed. by Gunzelin Schmid Noerr, trans. by Edmund Jephcott (Stanford, CA: Stanford University Press, 2002), 94-136. On the impact of consumer culture, see Anthony Elliot, "Social Theory and Psychoanalysis," in The Routledge Companion to Social Theory, ed. by Anthony Elliot (London: Routledge, 2010), 58-60. Further, as we embrace this technorationality, our family, our traditions, our culture and arts, our religions, and our morality which are supposed to elevate us above from the animal conditions have all been set aside to give way for the institutionalization of this type of mentality. See Simon Clarke, "The Neoliberal Theory of Society," in Neoliberalism: A Critical Reader, ed. by Alfredo Saad-Filho and Deborah Johnston (London: Pluto Press, 2005), 50-59.

${ }^{60}$ See Erich Fromm, "Freedom in the Work Situation," in Yearbook of the International Erich Fromm Society, 3 (1994), 2.

${ }^{61}$ See Pacquing, "Neoliberalism and the Paralysis of Human Rationality," 158.

62 See Helga Dittmar, Consumer Culture, Identity and Well-Being: The Search for the "Good Life" and the "Body Perfect" (New York: Psychology Press, 2007), 11-12.

(C) 2018 lan Raymond B. Pacquing

https://www.kritike.org/journal/issue 22/pacquing_june2018.pdf

ISSN 1908-7330

(cc) BY-NC-ND 
itself into storehouse of facts, events, and possessions. ${ }^{63}$ As a result, our Weltanschauung, i.e., the historical thread which is supposed to link our past, present, and future posterities are eliminated. We dwell in a world-less universe where individuality and subjectivity are delineated. ${ }^{64}$ Thus, what is left for us is the "I-am-me" mentality which isolates us from the locus of our existential domain. ${ }^{65}$ Our experience of our "self" as unique individual and as master of our "I" vanishes. ${ }^{66}$ What we have instead is inner turmoil that leads us towards contradictory ways of living, i.e., towards fragmented and compartmentalized lives. ${ }^{67}$ Undeniably, we have a pseudo-identity-a dead image. ${ }^{68}$ We don't experience our wholeness as a person for we are driven and alienated in ways that we are unconscious of. ${ }^{69}$ In this sense we acquire neurotic behaviors which are symptomatic of our own social characterology. ${ }^{70}$ That is why Fromm discusses that psychoanalytic therapy must plunge into the "radix" of our social dynamics for he believes that the real cause of neurotic or irrational behaviors is the alienated person who does not experience his wholeness as a person..$^{71}$

These deadening effects of our contemporary times, and principally, the destructive psychological nuances of our market economy, should lead us to understand and ponder those socio-structural policies that serve as the

\footnotetext{
${ }^{63}$ See Romano Biancoli, "The Search for Identity in the Being Mode," in Fromm Forum: Annual Publication of the International Erich Fromm Society, English ed., 10 (2006), 23-30.

64 See Robert Samuels, New Media, Cultural Studies, and Critical Theory after Postmodernism (New York: Palgrave Macmillan, 2009), 3. For the discussion of a world-less universe, see Slavoj Žižek, Living in the End Times (London: Verso, 2010), 40. See also Elisabeth Roudinesco, Why Psychoanalysis? trans. by Rachel Bowlby (New York: Columbia University Press, 2001), 3-10. The delineation of the individual as subject towards self-determination is discussed eloquently by Noonan. See Jeff Noonan, Critical Humanism and the Politics of Difference,
} 5 .

65 The social structures of automodernity interact with man to the extent that his psychic energy is deprived of its human base. See Tatjana Panfilova, "Identity as a problem of today," in Fromm Forum: Annual Publication of the International Erich Fromm Society, English ed., 14 (2010), 43-51.

${ }^{66}$ See Zima, Subjectivity and Identity, 6.

${ }^{67}$ See Edward T. Hall, "The Paradox of Culture," in In the Name of Life: Essays in Honor of Erich Fromm, ed. by B. Landis and E. S. Tauber (New York: Holt, Rinehart and Winston, 1970), $2-5$.

${ }^{68}$ See Biancoli, "The Search for Identity in the Being Mode." In the opinion of Hardt and Negri, our lives have been downgraded into the pit of deterritorializing apparatuses which wobble the center of human relationships. See Michael Hardt and Antonio Negri, Preface to Empire (London: Harvard University Press, 2000), xii-xv.

${ }^{69}$ See Fromm, Psychoanalysis and Zen Buddhism, 10-11.

${ }^{70}$ For Fromm's discussion of pathology of normalcy, see Fromm, The Sane Society, 12.

${ }^{71}$ For Fromm, an alienated person is estranged from himself, out of touch with himself. The individual does not experience himself as the center of his world. He rather creates an artificial world for himself. In the alienated individual, life is denied. Control, creativity, independent thought is all baulked and the inevitable result is a fight or flight on the part of the worker, apathy, destructiveness, and psychic regression. See Fromm, The Sane Society, 124-130. 


\section{FROMM'S REDEMPTIVE PSYCHOANALYTIC CRITIQUE}

raison d'état towards governance under the disguise of sovereignty. ${ }^{72}$ We have to be aware of the inconsistencies of these structural policies which cripple and paralyze human growth and development. ${ }^{73}$ We have to unravel the mysteries that lie behind the pathology of normalcy. ${ }^{74}$ Today, where everything is socially constructed and deconstructed, ${ }^{75}$ and with no human base of socialization, we instead have established in us the unholy trinity of uncertainty, unsafety, and insecurity that unconsciously batter our lives into anxiety, meaninglessness, and hopelessness. ${ }^{76}$ What we need is the recontextualization of our lives, i.e., a dynamic orientation that leads towards a development of an authentic, vital sense of self and a construction of personal meaning amidst the perplexity of a postmodern world. ${ }^{77}$ In this sense, social psychology brings back society to health and allows each individual to grow and mature in autonomy and social agency. ${ }^{78}$ This is our social discontents and I believe that we have to revisit and ponder once again a radical humanistic psychology that is found in the philosophy of Erich Fromm. ${ }^{79}$

Department of Philosophy, University of Santo Tomas, Philippines

72 See Michael Foucault, The Birth of Biopolitics: Lectures at the College de France, 1978-79, ed. by Michel Senellart, trans. by Graham Burchell (New York: Palgrave Macmillan, 2008), 32.

${ }^{73}$ See Pacquing, "Neoliberalism and the Paralysis of Human Rationality," 158.

${ }^{74}$ By pathology of normalcy, Fromm explains that the illusions resulting from our sociopolitical structures are now taken to be the normative paradigm of modern society. The consensual validation does not allow humanity to grow and develop as it should be. As a matter of fact, Fromm asserts that "The fact that millions of people share the same vices does not make these vices virtues, the fact that they share so many errors does not make the errors to be truths, and the fact that millions of people share the same forms of mental pathology does not make these people sane." See Fromm, The Sane Society, 12-16.

${ }^{75}$ In the book Identity Crisis, Dunn argues that with the rapid sociopolitical changes happening within a postmodern society, what we have is a fluid self, characterized by "fragmentation, discontinuity, and dissolution of boundaries between the inner and outer world." See Robert Dunn, Identity Crisis: A Social Critique of Postmodernity (London: Minnesota Press, 1998), 64. Consequently, we are reduced to matter, language, contexts, and constructions which are now the main values and essential reality in a postmodern setting. See Jon Frederickson, "The Problem of Relationality," in Relational and Intersubjective Perspectives in Psychoanalysis: A Critique, ed. by Jon Mills (New York: Jason Aronson, 2005), 72-73; 80-82.

${ }^{76}$ See Leonidas Donskis, Preface to Troubled Identity and the Modern World (New York: Palgrave Macmillan, 2009), ix.

77 Safran, Psychoanalysis and Buddhism, 6.

${ }^{78}$ See Buzby, Subterranean Politics and Freud's Legacy, 12.

${ }^{79}$ Fromm's radical psychoanalytic theory emphasized that relatedness, transcendence, and belongingness are the key essential features of growth and development. Cf. Durkin, The Radical Humanism of Erich Fromm, 70-75.

(C) 2018 lan Raymond B. Pacquing

https://www.kritike.org/journal/issue 22/pacquing_june2018.pdf

ISSN 1908-7330

(c) $\mathrm{BY}-\mathrm{NC}-\mathrm{ND}$ 


\section{References}

Biancoli, Romano, "The Search for Identity in the Being Mode," in Fromm Forum: Annual Publication of the International Erich Fromm Society, English ed., 10 (2006).

Buzby, Amy, Subterranean Politics and Freud's Legacy: Critical Theory and Society (New York: Palgrave Macmillan, 2013).

Chomsky, Noam, Chomsky, "Market Democracy in a Neoliberal Order: Doctrines and Reality," in Z Magazine (1 November 1997), $<$ https://zcomm.org/zmagazine/market-democracy-in-a-neoliberalorder-doctrines-and-reality-by-noam-chomsky-1/>. Profit Over the People: Neoliberalism and the Global Order (New York: Seven Stories Press, 1999).

Clarke, Simon, "The Neoliberal Theory of Society," in Neoliberalism: A Critical Reader, ed. by Alfredo Saad-Filho and Deborah Johnston (London: Pluto Press, 2005).

Dittmar, Helga, Consumer Culture, Identity and Well-Being: The Search for the "Good Life" and the "Body Perfect" (New York: Psychology Press, 2007).

Donskis, Leonidas, Troubled Identity and the Modern World (New York: Palgrave Macmillan, 2009).

Dunn, Robert, Identity Crisis: A Social Critique of Postmodernity (London: Minnesota Press, 1998).

Durkin, Kieran, The Radical Humanism of Erich Fromm (New York: Palgrave Macmillan, 2014).

Elliot, Anthony, "Social Theory and Psychoanalysis," in The Routledge Companion to Social Theory, ed. by Anthony Elliot (London: Routledge, 2010).

Erös, Ferenc, "Wilhelm Reich, Erich Fromm and the Analytical Social Psychology of the Frankfurt School," in the Erich Fromm Document Center (1992), <https://opus4.kobv.de/opus4-Fromm/files/8829/ Eroes F 1992.pdf>.

Foucault, Michel, The Birth of Biopolitics: Lectures at the College de France, 197879, ed. by Michel Senellart, trans. by Graham Burchell (New York: Palgrave Macmillan, 2008).

Frederickson, Jon, "The Problem of Relationality," in Relational and Intersubjective Perspectives in Psychoanalysis: A Critique, ed. by Jon Mills (New York: Jason Aronson, 2005).

Freud, Sigmund, Civilization and Its Discontents, trans. by James Strachey (New York: W.W. Norton \& Company, 1961).

Freud, Group Psychology and the Analysis of the Ego, in The Standard Edition of the Complete Psychological Works of Sigmund Freud, vol. 18, ed. and trans. by James Strachey (London: Hogarth Press).

(c) 2018 Ian Raymond B. Pacquing

https://www.kritike.org/journal/issue 22/pacquing june2018.pdf

ISSN 1908-7330

(cc) $\mathrm{BY}-\mathrm{NC}-\mathrm{ND}$ 


\section{FROMM'S REDEMPTIVE PSYCHOANALYTIC CRITIQUE}

Fromm, Erich, Beyond the Chain of Illusion (London: Simon and Schuster, 1962). Fear of Freedom (New York: Farrar \& Rinehart, 1942). "Freedom in the Work Situation," in Yearbook of the International Erich Fromm Society, 3 (1994). Heart of Man: Its Genius for Good and Evil (New York: Harper and Row, 1964).

"Man's Impulse Structure and Its Relation to Culture," in Beyond Freud: From Individual to Social Psychology, ed. by Rainer Funk (New York: American Mental Health Foundation, 2010). Marx's Concept of Man (London: Continuum, 1961).

"Psychoanalysis and Sociology," in Critical Theory and Society: A

Reader, trans. by Mark Ritter, ed. by Stephen Bronner and Douglas Kellner (New York: Routledge, 1989). Psychoanalysis and Zen Buddhism (New York: Open Road Media, 2013).

"Selfishness and Self-Love," in Yearbook of the International Erich Fromm Society, 5 (1994).

The Crisis of Psychoanalysis: Essays on Freud, Marx, and Social Psychology (New York: Henry Holt and Company, 1970).

The Dogma of Christ and Other Essays on Religion, Psychology, and Culture (New York: Rinehart and Co., 1995).

"The Method and Function of an Analytic Social Psychology," in The Essential Frankfurt School Reader, ed. by Andrew Arato and Eike Gebhardt (New York: Continuum, 2002).

The Sane Society (Canada: Holt, Rinehart, and Winston, 1955).

Funk, Rainer, Erich Fromm: The Courage to Be Human (New York: Continuum, 1982).

"Erich Pinchas Fromm and the Social Character," in The Edinburgh International Encyclopedia of Psychoanalysis, ed. by Ross M. Skelton (Edinburgh: Edinburgh University Press, 2006).

Foreword to Reclaiming the Sane Society: Essays on Erich Fromm's Thought, ed. by Seyed Javad Miri, Robert Lake, and Tricia M. Kress (Rotterdam: Sense Publisher, 2014).

"Fromm's Approach to Psychoanalytic Theory and Its Relevance for Therapeutic Work" (lecture given at the Instituto Mexicano de Psicoanálisis, A.C., 15 October 1992), < $\underline{\text { https://opus4.kobv.de/opus4- }}$ Fromm/files/9951/Funk R 1993h.pdf $>$.

"Living by the manual: Ego-oriented social characterpathogenic effects of globalization," in International Forum of Psychoanalysis 19:2 (2010).

(C) 2018 lan Raymond B. Pacquing

https://www.kritike.org/journal/issue 22/pacquing june2018.pdf

ISSN 1908-7330

(cc) BY-NC-ND 
"The Striving for Unboundedness and Its Impact on Psychoanalytic Treatment," in Fromm Forum: Annual Publication of the International Erich Fromm Society, English ed., 17 (2013).

Golding, Robert, "Freud, Psychoanalysis, and Sociology: Some Observations on the Sociological Analysis of the Individual," in The British Journal of Sociology, 33:4 (December 1982).

Gray, Mel, "Perspectives on Neoliberalism for Human Service Professionals" in Social Service Review, 89:2 (June 2015).

Hall, Edward T., "The Paradox of Culture," in In the Name of Life: Essays in Honor of Erich Fromm, ed. by B. Landis and E. S. Tauber (New York: Holt, Rinehart and Winston, 1970).

Hardt, Michael and Antonio Negri, Empire (London: Harvard University Press, 2000).

Harvey, David, Brief History of Neoliberalism (New York: Oxford University Press, 2005).

Honneth, Axel, Reification: A New Look at an Old Idea, ed. by Martin Jay (New York: Oxford University Press, 2008).

Horkheimer, Max and Theodor Adorno, "The Culture Industry: Enlightenment as Mass Deception," in The Dialectic of Enlightenment, ed. by Gunzelin Schmid Noerr, trans. by Edmund Jephcott (Stanford, CA: Stanford University Press, 2002).

Horrocks, Roger, Freud Revisited: Psychoanalytic Themes in the Postmodern Age (New York: Palgrave Macmillan, 2001).

Javors, Irene Rosenberg, "Revisiting Beyond the Chains of Illusion: My Encounter with Marx and Freud: Reflections on Fromm's Theory and Practice with the Psychotherapeutic Encounter," in Reclaiming the Sane Society: Essays on Erich Fromm's Thought, ed. by Seyed Javad Miri, Robert Lake, and Tricia M. Kress (Rotterdam: Sense Publisher, 2014).

Kellner, Douglas, "Erich Fromm, Feminism, and the Frankfurt School" (paper presented at the International Interdisciplinary Symposium on Erich Fromm and the Frankfurt School, Stuttgart-Hohenheim, 31 May to 2 June 1991), <https://pages.gseis.ucla.edu/faculty/kellner LIllumina\%20Folder/kell8.htm>.

Kessler, Michael and Rainer Funk, eds. Erich Fromm und die Frankfurter Schule (Tübingen: Francke Verlag, 1992).

Lasch, Christopher, The Culture of Narcissism (New York: W.W. Norton and Company, 1979).

Marx, Karl, A Contribution to the Critique of Political Economy, trans. by N.I. Stone (Chicago: Charles H. Kerr and Company, 1904).

Mitchell, Stephen A., Influence and Autonomy in Psychoanalysis (London: Routledge, 2013).

(C) 2018 lan Raymond B. Pacquing https://www.kritike.org/journal/issue 22/pacquing june2018.pdf ISSN 1908-7330 


\section{FROMM'S REDEMPTIVE PSYCHOANALYTIC CRITIQUE}

Noonan, Jeff, Critical Humanism and the Politics of Difference (London: McGill Queen's University Press, 2013).

Pacquing, Ian Raymond B., "Neoliberalism and our Precarious Culture," in Kritike: An Online Journal of Philosophy, 11:1 (2017).

"Neoliberalism and the Paralysis of Human Rationality," in Kritike: An Online Journal of Philosophy, 10:1 (June 2016).

Panfilova, Tatjana, "Identity as a problem of today," in Fromm Forum: Annual Publication of the International Erich Fromm Society, English ed., 14 (2010).

Parker, Ian, Revolution in Psychology: Alienation to Emancipation (London: Pluto Press, 2007).

Pekkola, Mikka, "Prophet of Radicalism: Erich Fromm and the Figurative Constitution of the Crisis of Modernity" (Ph.D. Dissertation, University of Jyvaskyla, 2010).

Rennison, Nick, Freud and Psychoanalysis (London: Pocket Essentials, 2001).

Rickert, John, "The Fromm-Marcuse Debate: Revisited," in Theory and Society, 15:3 (May 1986).

Ritzer, George, McDonaldization: The Reader (London: Fine Forge Press, 2002).

Roudinesco, Elisabeth, Why Psychoanalysis? trans. by Rachel Bowlby (New York: Columbia University Press, 2001).

Safran, Jeremy D., "Introduction: Psychoanalysis and Buddhism as Cultural Institutions," in Psychoanalysis and Buddhism: An Unfolding Dialogue, ed. by Jeremy D. Safran (Boston: Wisdom Publications, 2003).

Samuels, Robert, New Media, Cultural Studies, and Critical Theory after Postmodernism (New York: Palgrave Macmillan, 2009).

Sulloway, Frank, "Reassessing Freud's Case Histories: The Social Constructions of Psychoanalysis," in Isis, 82:2 (June 1991).

Weiss, Frederic A., "Self-Alienation, Psychoanalysis and the Wholeness of Man," in Fortschritte der Psychoanalyse. Internationales Jahrbuch zur Weiterentwicklung der Psychoanalyse, vol. 1, ed by A. Heigl-Evers (Göttingen: Verlag für Psychologie - Dr. C. J. Hofgrefe, 1964).

Wilde, Lawrence, Erich Fromm and the Quest for Solidarity (New York: Palgrave McMillan, 2005).

Zima, Peter V., Subjectivity and Identity: Between Modernity and Postmodernity (London: Bloomsbury, 2015).

Žižek, Slavoj, Living in the End Times (London: Verso, 2010).

(C) 2018 lan Raymond B. Pacquing

https://www.kritike.org/journal/issue 22/pacquing june2018.pdf

ISSN 1908-7330

(c) $)$ BY-NC-ND 